\title{
Communication
}

[Comunicação]

\section{Bothrops alternatus snake venom induces apoptosis of skeletal muscle cells in a rabbit model}

\author{
[O veneno da serpente Bothrops alternatus induz apoptose nas células musculares de coelhos] \\ W.G. Santos, T.L. Silveira, A.T.L. Fiúza, A.F.M. Botelho, I.N.N. Gonçalves, \\ E. Ferreira, B. Soto-Blanco, M.M. Melo
}

Universidade Federal de Minas Gerais - Belo Horizonte, MG

The toxic components of the venom from snakes belonging to the genus Bothrops induce serious changes in the inoculation site through several mechanisms. Currently, it is known that these local changes do not occur through the action of only one enzyme, but by combining several toxins that act synergistically, mainly zincdependent metalloproteinases (SVMPs) and $\mathrm{PLA}_{2}$ (Mamede et al., 2016). The intensity of these local effects may vary according to the Bothrops species as the concentration of its components are singular (Rocha and Furtado, 2005; Mamede et al., 2016). B. alternatus venom, for example, has a higher concentration of metalloproteinases (SVMP) of class P-III activity and the lesions generally present a better recovery as compared to other Bothrops species (Garcia Denegri et al., 2016).

The plasma membrane of the skeletal striated musculature is one of the first structures affected by these components (Gutiérrez and Lomonte, 1995). Local changes appear in a hyper acute way, with the presence of edema, hemorrhage, inflammation and myonecrosis (Gutiérrez and Lomonte, 1995; Gutiérrez et al., 2016). The involvement of apoptosis mechanisms via caspase- 3 in the cytotoxicity on skeletal striated musculature resulting from $B$. alternatus snake venom has been reported in vitro. Baltergina, a P-III SVMP, may be primarily responsible for this mechanism in venom of this specie of snake (Bustillo et al., 2017). The purpose of this study is to report the in vivo occurrence of apoptosis

Recebido em 6 de junho de 2017

Aceito em 7 de março de 2018

Autor para correspondência (corresponding author)

E-mail: marilia.melo@pq.cnpq.br induction, via caspase- 3 , by $B$. alternatus snake venom in rabbit muscle cells.

A pool of venom collected from adult $B$. alternatus specimens was crystallized and stored at $-20^{\circ} \mathrm{C}$ until the time of use. The venom underwent polyacrylamide gel electrophoresisSDS-PAGE, according to Schneider et al., (2014). The crude crystallized venom was suspended in $0.9 \% \mathrm{NaCl}$ solution and then diluted in $0.1 \%$ BSA in PBS solution for administration in the animals. Ten male adult New Zealand rabbits, weighing between 2.1 and $3.4 \mathrm{~kg}$ were used. Five of these animals were injected with $150 \mu \mathrm{g} / \mathrm{kg}$ of venom from $B$. alternatus in the vastus lateralis muscle of the left thigh. The other five rabbits (control group) were injected with $0.1 \%$ BSA in PBS solution in the same muscle.

Twelve hours later, euthanasia was performed by intravenous injection of thiopental overdose. Muscle fragments from the venom application site were collected and fixed for 24 hours in $10 \%$ buffered formalin and then stored in $70 \%$ alcohol solution for routine histological processing, hematoxylin-eosin staining (H\&E), and immunohistochemistry for caspase-3. Histological sections of $4 \mu \mathrm{m}$ of muscle tissue were obtained on gelatinized glass slides.

These slides were deparaffinized in an oven at $60^{\circ}$ for 30 minutes to perform the immunohistochemistry technique according to Freitas et al. (2007). The primary antibody used was anti-caspase-3 (clone Ab-4, dilution 1:300), 
with an overnight incubation time at $8^{\circ} \mathrm{C}$ and the colorimetric revelation was performed with the substrate diaminobenzidine (DAB) Novolink $^{\mathrm{TM}}$ R87280, Novovasctra). Counterstaining was done using Mayer's Hematoxylin. Cases with cytoplasmic and nuclear marking on muscle fibers by caspase- 3 were considered positive.

The B. alternatus venom used in the present study had a large number of SVMPs with bands of $14 \mathrm{kDa}$, considered the $\mathrm{PLA}_{2}$. Both the snake venom SVMPs and the $\mathrm{PLA}_{2}$ are responsible for local effects from $B$. alternatus snake venom (Mamede et al., 2016).
In our study, the histological evaluation of the muscles showed intense myonecrosis and hemorrhage at site of venom injection (Figure 1). No significant change was found in the muscles of control rabbits. The immunohistochemistry reaction for activated caspase- 3 in the muscles of venom injected rabbits showed granular and aggregated staining in muscle fiber cytoplasm (Figure 2A). This staining is compatible with activation of apoptosis mechanisms in the muscle cells by the crude venom of $B$. alternatus. On the other hand, no reaction was found in the muscles from the control group (Figure 2B).



Figure 1. A, B. Histological sections of vastus lateralis muscle showing large hemorrhage area (asterisk) and intense predominantly polymorphonuclear inflammatory infiltrate (arrows) at the site of inoculation of $B$. alternatus snake venom, compatible with hemorrhagic necrosis (H\&E staining, bar $=50 \mu \mathrm{m})$.

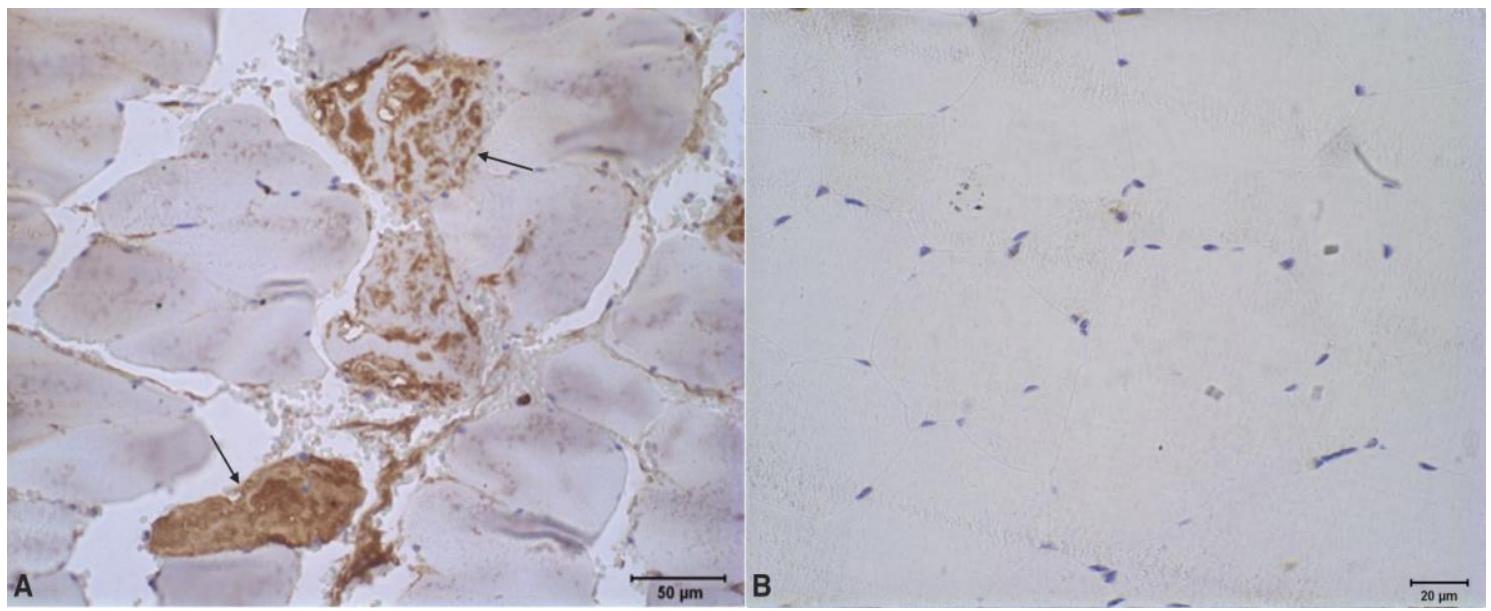

Figure 2. Activated caspase-3 immunohistochemistry of vastus lateralis muscle from rabbits at the site of inoculation of $B$. alternatus snake venom (A) or $0.1 \%$ BSA in PBS solution (B). A. Granular and aggregated staining in the cytoplasm (arrows), compatible with cells in apoptosis (bar= $50 \mu \mathrm{m}$ ). B. Negative staining (bar $=20 \mu \mathrm{m})$. 
A small IM dose of B. alternatus venom $(80 \mu \mathrm{g})$ causes intense local hemorrhage and severe local myonecrosis in the first 24 hours (Queiroz and Petta, 1984). Similarly, low doses, ranging from 50 to $100 \mu \mathrm{g}$, administered in the gastrocnemius muscle of mice caused severe changes in the local vasculature, culminating in hemorrhage, evident inflammation and myonecrosis, with recovery at 28 days (Garcia Denegri et al., 2016).

Although necrosis is a known lesion caused by this venom, apoptosis may also play a role in the death of muscle cells. Previous in vitro studies suggested that the apoptosis mechanism triggered by $B$. alternatus snake venom is related to a class P-III SVMP, called baltergine. This toxin induces cell death through reduction of adhesion to the extracellular matrix (anoikis) and interaction with integrins (Bustillo et al., 2017).

Other in vitro studies have evaluated the cytotoxic effects of venoms from different species of snakes. A myotoxic PLA 2 isolated from the venom of Bothrops jararacussu, called BthTX-I, had cytotoxic action, mainly by apoptosis on cultures of promyelocytic leukemia cells, human hepatocellular carcinoma, murine pheochromocytoma, and murine melanoma (Prinholato da Silva et al., 2015). In addition, an acid L-amino oxidase from Bothrops pirajai venom induced apoptosis in neoplastic cell cultures (Burin et al., 2013). In another experiment using cultured murine muscle cells (C2C12), B. alternatus and B. diporus venoms produced cytotoxicity by apoptosis, evidenced by morphological changes typical of the process such as condensation of chromatin, nuclear fragmentation, bubble formation on the cell surface, and reduction of cell size (Bustillo et al., 2009).

Cell apoptosis can be evaluated by caspase- 3 expression, as proposed in the present work. Studies in the last decades have proved that proteases play critical role in the apoptosis process. Caspases are one of the most important regarding this cell death. These proteases are synthesized as inactive zymogens that become active after transactivatated or cleaved. Once activated, they can disrupt different cytoplasmic and nuclear polypeptides that may alter important components of the cells, including architectural, biochemical and morphological proteins. Once these changes occur, the apoptosis process is installed. Among the several caspases, caspase-3 is considered to be the main executioner of this process and represent one of the final steps towards cell death (Mcllwain et al., 2013).

The crude venom of $B$. alternatus causes severe local myonecrosis and hemorrhage. The observed activation of caspase-3 suggests the occurrence of apoptosis that might contribute to myocytes death.

Keywords: snake venom, botropic venom, apoptosis, toxicology, rabbit

\section{RESUMO}

Este estudo objetiva reportar a ocorrência de apoptose in vivo induzida pelo veneno da serpente Bothrops alternatus em células musculares esqueléticas. Cinco coelhos machos, adultos, receberam $150 \mu \mathrm{g} / \mathrm{kg}$ de veneno no músculo vasto lateral, enquanto outros cinco animais receberam 0,1\% de BSA diluído em PBS no mesmo local. Após 12 horas, os animais foram eutanasiados, e amostras do local de inoculação foram coletadas para análise histopatológica. Foram evidenciadas necrose e hemorragia nas células musculares. Além disso, a análise imuno-histoquímica para identificação de caspase-3 ativada revelou marcações granulares e agregadas no citoplasma das células musculares, compatíveis com o processo de apoptose. Este é o primeiro relato que confirma o veneno de B. alternatus como causador de apoptose in vivo em células musculares esqueléticas.

Palavras-chave: envenenamento ofídico, veneno botrópico, apoptose, toxinologia, coelho

\section{ETHICAL STATEMENT}

The experimental protocol of this study was approved by the Ethics Committee on the Use of
Animals of the Universidade Federal de Minas Gerais (CEUA-UFMG - protocol number 274/2015) and carried out in accordance with ethical principles of animal care and welfare. 


\section{ACKNOWLEDGEMENT}

This work was supported by the Conselho Nacional de Desenvolvimento Científico e Tecnológico - CNPq under Grant 305462/20130 .

\section{REFERENCES}

BURIN, S.M.; AYRES, L.R.; NEVES, R.P. et al. L-amino acid oxidase isolated from Bothrops pirajai induces apoptosis in BCR-ABL-Positive cells and potentiates imatinib mesylate effect. Basic Clin. Pharmacol. Toxicol., v.113, p.103112, 2013.

BUSTILLO, S.; LUCERO, H.; LEIVA, L.C. et al. Cytotoxicity and morphological analysis of cell death induced by Bothrops venoms from the northeast of Argentina. J. Venom. Anim. Toxins Incl. Trop. Dis., v.15, p.28-42, 2009.

BUSTILLO, S.; VAN DE VELDE, A.C.; MATZNER PERFUMO, V. et al. Apoptosis induced by a snake venom metalloproteinase from Bothrops alternatus venom in $\mathrm{C} 2 \mathrm{C} 12$ muscle cells. Apoptosis, v.22, p.491-501, 2017.

FREITAS, E.S.; LEITE, E.D.; SOUZA, C.A. $e t$ al. Histomorphometry and expression of $\mathrm{Cdc} 47$ and caspase- 3 in hyperthyroid rat uteri and placentas during gestation and postpartum associated with fetal development. Reprod. Fertil. Dev., v.19, p.498-500, 2007.

GARCIA DENEGRI, M.E.; TEIBLER, G.P.; MARUÑAK, S.L. et al. Efficient muscle regeneration after highly hemorrhagic Bothrops alternatus venom injection. Toxicon, v.122, p.167-175, 2016.
GUTIÉRREZ, J.M.; ESCALANTE, T.; RUCAVADO, A. et al. Hemorrhage caused by snake venom metalloproteinases: a journey of discovery and understanding. Toxins, v.8, p.119, 2016.

GUTIÉRREZ, J.M.; LOMONTE, B. Phospholipase $\mathrm{A}_{2}$ myotoxins from Bothrops snake venoms. Toxicon, v.33, p.1405-1424, 1995.

MAMEDE, C.C.; DE SOUSA, B.B.; PEREIRA, D.F. et al. Comparative analysis of local effects caused by Bothrops alternatus and Bothrops moojeni snake venoms: enzymatic contributions and inflammatory modulations. Toxicon, v.117, p.37-45, 2016.

MCLLWAIN, D.R.; BERGER, T.; MAK, T.W. Caspase functions in cell death and disease. Cold Sprin. Harb. Perspect. Biol., v.5, 2013.

PRINHOLATO DA SILVA, C.; COSTA, T.R.; PAIVA, R.M. et al. Antitumor potential of the myotoxin BthTX-I from Bothrops jararacussu snake venom: evaluation of cell cycle alterations and death mechanisms induced in tumor cell lines. J. Venom. Anim. Toxins Incl. Trop. Dis., v.21, p.1-8, 2015.

QUEIROZ, L.S.; PETTA, C.A. Estudo histopatológico das lesões causadas pelo veneno de urutu (Bothrops alternatus) em músculo esquelético de camundongos. Rev. Inst. Med. Trop. S. Paulo, v.26, p.247-253, 1984.

SCHNEIDER, F.S.; LE NIGUYEN, D.; CASTRO, K.L. et al. Use of a synthetic biosensor for neutralizing activity-biased selection of monoclonal antibodies against atroxlysin-I, an hemorrhagic metalloproteinase from Bothrops atrox snake venom. PLoS Neglected Trop. Dis., v.8, p.1-9, 2014. 